\title{
Entrepreneurial Innovations in Countries at Different Stages of Development
}

\author{
Éva Komlósi \\ Research Fellow, MTA-PTE Innovation and Economic Growth Research Group, Regional Innovation and \\ Entrepreneurship Research Center (RIERC) ${ }^{\text {a }}$, komlosieva@ktk.pte.hu

\section{Balázs Páger} \\ Visiting collaborator, Institute for Regional Studies ${ }^{\mathrm{b}}$, and external collaborator, RIERC ${ }^{\mathrm{a}}$, pagerb@rkk.hu
}

\author{
Gábor Márkus \\ Adjunct Professor, Faculty of Business and Economics, Department of Finance and Accounting, and \\ Research Fellow, RIERCa, markus@ktk.pte.hu \\ ${ }^{a}$ University of Pécs, Pécs, 48-as tér 1, 7622, Hungary \\ ${ }^{\mathrm{b}}$ Centre for Economic and Regional Studies(CERS), Hungarian Academy of Sciences, \\ 1097 Budapest Tóth Kálmán u. 4, Hungary
}

\begin{abstract}
$\mathrm{T}$ he aim of our paper is to provide a comprehensive picture of the role of innovation within the entrepreneurial ecosystem in certain countries. In this way, we propose the following research question as to what kind of interrelatedness can be observed between the innovation capability of a country and other elements of its entrepreneurial ecosystem. Ninety-five countries have been involved in our analysis, which initially have been grouped by their level of economic development and a group of transition countries has been created as well. In order to measure these relations, the Global Entrepreneurship Index (GEI) was applied. This index measures the qualitative aspects of the entrepreneurial ecosystem in a national context. The index consists of fourteen pillars covering the relevant aspects of the entrepreneurial ecosystem. Out of the pillars, there are three pillars associated with three different aspects of innovation: Technology Absorption, Product Innovation, and Process Innovation. After analyzing the pillars, we conducted a k-means cluster analysis in order

to demonstrate whether countries with the same level of development are ranked in a common group if they are clustered by the values of the three innovation pillars. Our results suggest that the quality of the entrepreneurial ecosystem reflects the level of economic development. Regarding the role of innovation, it seems that the innovation-related pillars have an important role within the entrepreneurial ecosystem. Technology Absorption is highly related to the GEI score and the level of economic development since the most developed countries have the highest values for this pillar. While the Product and Process Innovation pillars have a relatively strong relationship with GEI score as well, it seems that a couple of countries have higher pillar values in these innovation-related pillars than the position of their GEI scores would lead one to expect. This may indicate that these countries have relatively good performance in research and development, but other components of their entrepreneurial ecosystem may hamper the exploitation of the results achieved by new firms.
\end{abstract}

Keywords: entrepreneurial ecosystem; Global Entrepreneurship Index (GEI); innovation; economic development; technology absorption

Citation: Komlósi E., Páger B., Márkus G. (2019) Entrepreneurial Innovations in Countries at Different Stages of Development. Foresight and STI Governance, vol. 13 , no 4, pp. 23-34. DOI: $10.17323 / 2500-$ 2597.2019.4.23.34 
$\mathrm{T}$ here is a general consensus that knowledge is the most fundamental source of the modern economy [Jaffe, Trajtenberg, 2002] and that innovation has become a "ubiquitous phenomenon" [Lundvall, 1992].

It follows from the above that the literature dealing with innovation and technological change has become enormous. This literature, on the one hand, primarily tries to answer the following fundamental question: what role does innovation play in economic growth? The New (Endogenous) Growth Theory (initiated by [Romer, 1986; Lucas, 1988; Rebelo, 1991]) tries to answer this question. Initially, it was assumed that knowledge is freely available to anyone and technological opportunities are equally available in all countries. However, it has been convincingly proven in the literature of knowledge spillovers that the accessibility of some types of knowledge is bounded by geographic proximity [Jaffe, 1989; Acs et al. 1994; Anselin et al. 1997; Varga 1998, 2000; Acs, Varga 2002; Feldman, 1999; Audretsch, Feldman, 2004; Boschma, 2005] and that an excludable or imperfectly accessible part of knowledge exists, which is characterized by novel, tacit elements and it is accessible only by interactions among agents in a system of innovation [Dosi, 1988].

The other, vast part of the innovation literature concentrates on the identification of conditions or factors that determine knowledge creation (especially new technological knowledge, as it is the most valuable type of knowledge in innovation) and its diffusion. The pivotal question that needs to be answered here is the following: how does technological change occur, and what are the key processes and institutions involved? The New Economics of Innovation (initiated by [Nelson, 1993; Lundvall, 1988, 1992; Freeman, $1982,1995]$ ) tries to give an answer to this question by focusing on the institutional arrangements in which the innovative processes take place. Innovation economics has been influenced by different theories of innovation such as interactive learning theories [Lundvall, 1992] and evolutionary theories, most importantly the New Institutional Economics (NIE, initiated by [Coase, 1992, 1998; North, 1989, 1990, 1991; Williamson, 1985, 2000]). NIE states that in formal social and formal legal norms and rules (i.e. institutions) underlie economic activity and leads researchers of innovation economics to posit that the interactive, iterative, and cumulative process of learning is a socially embedded process, therefore it cannot be understood without taking into consideration the institutional and cultural context [Carlsson et al., 2002].

The National Systems of Innovation (NSI, or elsewhere National Innovation System - NIS) seemed to be a fruitful approach for the study of innovation and technical change in the economy [Edquist, 1997]. According to NSI, knowledge is the most fundamental resource in the economy, and "knowledge is produced and accumulates through an interactive and cumulative process of innovation that is embedded in a national institutional context, and that the context, therefore, matters for innovation outcomes" [Ács et al., 2014, p. 477].

Paradoxically, because of the strengthening of globalization, regional scientists, economic geographers, and innovation analysts noticed that the concept of the National System of Innovation may be questionable given that recognition has increased that important elements of the process of innovation tend to become regional rather than national [Cooke, 2001]. The importance of the national level as social agreements that influence learning and technology is further emphasized by [Freeman, 2002; Lundvall et al., 2002]. At the same time, the sub-national level, which includes clusters and regions, has increasingly become an area of interest. National institutions may influence innovation systems at regional, sectoral, or technological levels differently, and not all institutions are national [Carlsson, 2006]. For large firms, national institutions may be more important, while for SMEs, regional institutions play a crucial role [Wixted, 2009]. All the aforementioned theories (in fact the whole innovation literature) can be integrated to develop a model of technology-led regional economic development by channeling those into a more general regional economic growth model [Acs, Varga, 2002]. Consequently, the concept of the Regional Innovation System (RIS) broke away relatively quickly [Cooke, 2001].

Meanwhile, the system perspective appeared in the field of strategic management as well, where the socalled business-system approach has become very popular. The National Business System (NBS) examines important structural and strategic factors that affect a firm's ability to capture a large share of the total value created by the ecosystem when organizing economic activity among their ecosystem partners [Whitley, 1994, 1996]. The fundamental difference between the two approaches is the focus of the analysis: while the NBS explains international differences in firm organization and behavior, the NSI is taking innovation as its focal point by emphasizing the limited mobility of technical competencies. However, both theoretical concepts, in spite of these differences, share the common idea that the national institutional framework appears at the center of the analysis.

In sum, we can note that economic development literature (which comprises a family of related concepts, including the National System of Innovation as well), on the one hand and the National Business System (NBS) have largely ignored the role of entrepreneurs [Acs et al., 2018], only referring to the 'firm' or 'enterprise' as a black box [Spigel, Harrison, 2018; Malecki, 2018] from the point of strategic management. An entrepreneur is the one who creates innovation through new combinations of former 
knowledge elements and creating new value (out$p u t)$. On the other hand, the entrepreneur contributes to employment and economic growth (outcome) due to his/her entrepreneurial activity (establishing and organizing a firm).

Both theories ignore the fact that, in spite of the abundance of resources, the extent of access to them can be severely limited by the entrepreneur's knowledge absorption ability, which on the one hand refers to the personal traits of the entrepreneur and on the other, indicates the degree of his/her social embeddedness [Qian, Acs, 2013; Qian, Jung, 2017; Qian, 2018].

In recent years, the concept of the Entrepreneurial Ecosystem (EE, or elsewhere System of Entrepreneurship) has become a hot topic in entrepreneurial research. The number of scientific publications dealing with this concept has spectacularly multiplied recently and the term itself has become a buzzword [Spigel, Harrison, 2018; Ritala, Gustafsson, 2018].

Briefly, the EE concept is based on what the other two concepts - NSI and NBS - have ignored: the entrepreneur. In contrast to the institutional emphasis of the National Systems of Innovation frameworks, where institutions engender and regulate action, Systems of Entrepreneurship are driven by individuals, with institutions regulating who acts and the outcomes of individual action [Acs et al., 2014]. The main feature of the EE concept is that it reflects the multi-dimensional nature of entrepreneurship. It assumes that a large number of different factors have an effect on entrepreneurship and emphasizes the importance of their interrelatedness as the main qualitative determinant for entrepreneurial performance.

The Global Entrepreneurship Index (GEI) has been elaborated upon to measure this qualitative aspect of the entrepreneurial ecosystem in a national context [Acs, Szerb, 2011, 2012; Acs et al., 2014]. Our index is based on the theoretical considerations of the EE concept, because it reflects the multi-dimensional nature of entrepreneurship by combining the individual entrepreneurial feature and the contextual institutional factors. The index consists of 14 pillars that can cover many, but not all, relevant aspects of the entrepreneurial ecosystem. Furthermore, by calculating the index, we apply a novel methodology, the Penalty for Bottleneck algorithm that incorporates the system perspective, therefore interactions between the pillars is expressed.

\section{An Overview of the Evolution of the EE Concept}

Nine studies have been identified as exhausting reviews providing a comprehensive overview of the entrepreneurial ecosystem published in the last few years in high impact peer-reviewed journals (see them in Table 1). These papers also formulate some critical remarks in order to draw attention to some controversial and unanswered aspects of the concept.

Despite the popularity of the EE concept, the literature underlines only a few relevant results: although the concept is very "seductive" [Stam, 2015, p. 1764], it is still very "chaotic" [Spigel, Harrison, 2018, p. 152], as it is based on only a few systematic and consistent empirical results, and has developed without any accepted clear definition or unambiguously proven theoretical framework [Stam, 2015; Mason, Brown, 2014; Motoyama, Knowlton, 2017].

The different definitions of the concept point out the divergent views on the EE concept. Despite the different definitions, a common feature of ecosystems is that they are heterogeneous. The main advantage of the EE concept that it can reflect the multi-dimensional nature of entrepreneurship. It is assumed that a huge number of different agents and factors have an effect upon entrepreneurship and their interrelatedness is the main qualitative determinant of entrepreneurial performance. However, researchers still do not know what the most important determining factors are or how these factors can be identified. It is now clear that ecosystems are complex systems, therefore they cannot be copied or simply adapted for other systems [Neck et al., 2004] and cannot be reproduced elsewhere because the development of an ecosystem is shaped by many unpredictable events (external and internal shocks). Therefore, one of the basic features of the ecosystems that they are sensitive to initial conditions [Roundy et al., 2017]. These conditions, besides the aforementioned general rules, cause the uniqueness of every ecosystem. However, many authors point out that studies do not provide a sufficient explanation about the evolution of the ecosystems. Recording those factors that presumably influence ecosystems does not offer useful knowledge since the importance of the factors can change over time. Therefore, if we want to understand how an ecosystem works as a system, causality among other factors should be explained.

There is also a consensus among researchers that the entrepreneur is the key player in the creation and operation of the ecosystem. The other players are more likely to be so-called 'feeders' [Cavallo et al., 2018], that is, a person who supports the ecosystem or provides different resources. At present, the examination of the relationships between actors is a central issue in ecosystem research [Zhang, Guan, 2017]. This is the area where the least progress has been made over the past 25 years [Roundy et al., 2017]. Some researchers mention the lack of a holistic approach suggesting that all relevant factors should be taken into account in measuring ecosystems. Others point out to the undesirable phenomenon of the "holistic approach" and they presume that each fac- 
tor has its own relative weight [Roundy et al., 2017]. This uncertainty can only be mitigated by exploring the causal relationship between the influencing factors [Stam, Spigel, 2016; Spigel, Harrison, 2018].

Several researchers suggest applying the process approach instead of identifying different factors influencing the ecosystems. Two processes can be identified here: the process of generating resources and the flow of resources between different actors. Initially, we can assume that only a few links exist among the actors, they rely only on some resources and operate without a supportive business culture. However, early entrepreneurial success can reinforce a positive social attitude towards entrepreneurship. Consequently, new resources accumulate within the region, the skills of the local workforce increase, new companies, human and financial resources appear increasingly frequently. All this contributes to the evolution of a positive entrepreneurial culture, which offers new impetus for the processes. In order to analyze these processes, some researchers have recommended network analysis as a potential methodology to explore the relationships between the actors [Roundy et al., 2017, 2018; Roundy, 2019].

The identification of the appropriate level of ecosystems is also an iportant issue. The local nature of the phenomenon is clear [Stam, 2015]. While ecosystems could have boundaries, these borders are not too sharp and remote. The main problem is to idetify the distinctive criteria of belonging to an ecosystem based on the notion that ecosystems are open systems, as they can attract resources from in and out. Multi-scalar analysis seems to be a proper tool to be able to understand the local-global relationships of ecosystems [Alvedalen, Boschma, 2017].

Ultimately, these review studies summarize the problematic issues of the entrepreneurial ecosystem and try to point out the areas that require further research. The Global Entrepreneurship Index can offer a solution for some of these fields by identifying the most important constituents and most hindering bottlenecks of the ecosystem, while taking into consideration the connection of the elements as well.

\section{GEI: Measuring the Performance of the Entrepreneurial Ecosystem}

While earlier analyses often focused on single in dicators such as startup rates or Total Early-phased Entrepreneurial Activity (TEA), more recent entrepreneurial research has shifted to a more systemic and multidimensional understanding of entrepreneurship at the national level. Based on the incon- sistencies of the definition, measurement, and the policy domain of entrepreneurship, the Global Entrepreneurship Index (GEI) was developed to measure country level entrepreneurship [Acs, Szerb, 2011, 2012; Acs et al., 2014].

The GEI is an annual index that measures the health of entrepreneurial ecosystems at the country level and ranks the performance of 137 countries against one another. The index is based on the theoretical concept of the National System of Entrepreneurship that "(...) is the dynamic, institutionally embedded interaction between entrepreneurial attitudes, abilities, and aspirations by individuals, which drives the allocation of resources through the creation and operation of new ventures" [Acs et al., 2014, p. 479] that requires a complex measure. Instead of using an output-related quantitative approach to entrepreneurship, a proper measure should focus on the qualitative aspects of entrepreneurship. The GEI includes both the individual efforts and capabilities and the environmental and institutional aspect of entrepreneurship as well as the fact that these different components constitute a system where the relationship between the elements is vital.

The first version of the GEI was initially called the Global Entrepreneurship and Development Index (GEDI) and has been followed by yearly reports since 2011. The GEI has gone through many smaller changes since its introduction and was extensively reviewed and renewed in 2016 [Acs, Szerb, 2016]. Our composite index proposes five levels of index building. This includes the GEI super index ${ }^{1}$ measuring entrepreneurship at the country level, the three subindexes (Entrepreneurial Attitudes, Entrepreneurial Abilities, and Entrepreneurial Aspirations), 14 pillars, 28 variables, and 49 indicators. All pillars were created by using an individual and an institutional (contextual) variable component (Table 2). The GEDI methodology collects data on the entrepreneurial attitudes, abilities and aspirations of the local population and then weights these against the prevailing social and economic "infrastructure" [Acs et al., 2018]. Entrepreneurial attitudes reflect the attitudes of the adult population toward entrepreneurship. Entrepreneurial abilities include some of the important characteristics of entrepreneurs that determine the extent to which new start-ups will have the potential for growth. Entrepreneurial aspirations refer to the distinct, qualitative, and strategy-related nature of the entrepreneurial activity [Acs et al., 2014].

The aim of our paper is to provide a comprehensive picture of the role of innovation within the entrepreneurial ecosystem in the involved countries. In

Acs et al. [Acs et al., 2018] provide a detailed description of the contents of the pillars, their variables and indicators as well as the methodology and calculation in the Technical Annex of latest version of GEI: https://thegedi.org/wp-content/uploads/dlm_uploads/2017/12/2018-GEI-Technical-Annex.pdf 
Table 1. Literature Review of Works on EE

\begin{tabular}{|c|c|c|c|c|}
\hline Author(s) & Title & Journal & $\begin{array}{c}\text { Year of } \\
\text { publication }\end{array}$ & Reference \\
\hline $\begin{array}{l}\text { Zoltan Acs, Erik Stam, } \\
\text { David Audretsch, } \\
\text { Allan O'Connor }\end{array}$ & $\begin{array}{l}\text { The Lineages of the Entrepreneurial } \\
\text { Ecosystem Approach }\end{array}$ & $\begin{array}{l}\text { Small Business } \\
\text { Economics }\end{array}$ & 2017 & [Acs et al., 2017] \\
\hline $\begin{array}{l}\text { Janna Alvedalen, Ron } \\
\text { Boschma }\end{array}$ & $\begin{array}{l}\text { A Critical Review of Entrepreneurial } \\
\text { Ecosystems Research: Towards a Future } \\
\text { Research Agenda }\end{array}$ & $\begin{array}{l}\text { European Planning } \\
\text { Studies }\end{array}$ & 2017 & $\begin{array}{l}{[\text { Alvedalen, }} \\
\text { Boschma, 2017] }\end{array}$ \\
\hline $\begin{array}{l}\text { Angelo Cavallo, Antonio } \\
\text { Ghezzi, Raffaello Balocco }\end{array}$ & $\begin{array}{l}\text { Entrepreneurial Ecosystem Research: } \\
\text { Present Debates and Future Directions }\end{array}$ & \begin{tabular}{|l} 
International \\
Entrepreneurship \\
Management Journal \\
\end{tabular} & 2018 & $\begin{array}{l}\text { [Cavallo et al., } \\
\text { 2018] }\end{array}$ \\
\hline $\begin{array}{l}\text { Elizabeth Mack, } \\
\text { Heike Mayer }\end{array}$ & $\begin{array}{l}\text { The Evolutionary Dynamics of } \\
\text { Entrepreneurial Ecosystems }\end{array}$ & Urban Studies & 2016 & $\begin{array}{l}\text { [Mack, Mayer, } \\
\text { 2016] }\end{array}$ \\
\hline Edward Malecki & $\begin{array}{l}\text { Entrepreneurship and the Entrepreneurial } \\
\text { Ecosystem }\end{array}$ & Geography Compass & 2018 & [Malecki, 2018] \\
\hline $\begin{array}{l}\text { Philip Roundy, Beverly } \\
\text { Brockman, Mike Bradshaw }\end{array}$ & $\begin{array}{l}\text { The Resilience of Entrepreneurial } \\
\text { Ecosystems }\end{array}$ & $\begin{array}{l}\text { Journal of Business } \\
\text { Venturing Insights }\end{array}$ & 2017 & $\begin{array}{l}\text { [Roundy et al., } \\
\text { 2017] }\end{array}$ \\
\hline $\begin{array}{l}\text { Philip Roundy, } \\
\text { Mike Bradshaw, } \\
\text { Beverly Brockman }\end{array}$ & $\begin{array}{l}\text { The Emergence of Entrepreneurial } \\
\text { Ecosystems: A Complex Adaptive Systems } \\
\text { Approach }\end{array}$ & $\begin{array}{l}\text { Journal of Business } \\
\text { Research }\end{array}$ & 2018 & $\begin{array}{l}\text { [Roundy et al., } \\
\text { 2018] }\end{array}$ \\
\hline $\begin{array}{l}\text { Ben Spigel, } \\
\text { Richard Harrison }\end{array}$ & $\begin{array}{l}\text { Toward a Process Theory of } \\
\text { Entrepreneurial Ecosystems }\end{array}$ & $\begin{array}{l}\text { Strategic } \\
\text { Entrepreneurship Journal }\end{array}$ & 2018 & $\begin{array}{l}\text { [Spigel, Harrison, } \\
2018]\end{array}$ \\
\hline Erik Stam & $\begin{array}{l}\text { Entrepreneurial Ecosystem and Regional } \\
\text { Policy: A Sympathetic Critique }\end{array}$ & $\begin{array}{l}\text { European Planning } \\
\text { Studies }\end{array}$ & 2015 & {$[$ Stam, 2015] } \\
\hline
\end{tabular}

this way, we propose the following research question: what kind of interrelatedness can be observed between the innovation capability of a country and the other elements of its entrepreneurial ecosystem?

In order to answer this question, the GEI and its three innovation-related pillar values were investigated in this paper. Since GEI is an annually calculated index, here, we applied the average values for 2012-2016 to filter out annual variations and potential sampling errors. First, we analyze the connection between GEI scores and the level of development. Second, to have a deeper insight into the role of innovation within different ecosystems, we compare the three GEI sub-indexes and the three innovation-related pillars of GEI (technology absorption, product innovation, and process innovation) (Table 3 ). The Technology Absorption pillar reflects the technologyintensity of a country's start-up activity combined with a country's capacity for firm-level technology absorption. The Product Innovation pillar captures the tendency of entrepreneurial firms to create new products weighted by the technology transfer capacity of a country. Finally, the Process Innovation pillar refers to the use of new technologies by start-ups combined with the potential of a country to conduct applied research.
Although the latest version of the GEI report contains 137 countries, our investigation applies average data for a five-year period. Therefore, some countries have been excluded due to missing data so our analysis includes 95 countries altogether. Countries are classified based on their level of economic development as resource-, efficiency- and innovationdriven economies (see the list of countries in Table 4). The first group (19 countries) involves countries whose GDP per capita is in the lowest third. Their economies are based mostly on the exploitation of different natural resources. Efficiency-driven countries have a moderate level of economic development (42 countries). They show a higher level of economic development compared to resourcedriven economies. Innovation-driven countries (34 countries) represent a relatively high level of economic development, as their economies operate relatively efficiently compared to the other groups. Their development path is based on innovation and new products mostly. This suggests that innovation may have a more important role in those countries' entrepreneurial ecosystems, who have higher level of development. A fourth group is a special cluster that has been created involving post-socialist transition countries ${ }^{2}$ (16 countries). Most of its members belong to efficiency-driven economies, a few

\footnotetext{
2 "Transition" refers to those countries whose political and economic systems changed from the socialist political system and planned economy to a democratic political structure and market economy.
} 


\section{Table 2. The Structure of the Global Entrepreneurship Index (GEI)}

\begin{tabular}{|c|c|c|}
\hline Sub-indexes & Pillars & Variables (individual/institutional) \\
\hline \multirow{10}{*}{ Attitudes sub-index } & \multirow{2}{*}{ Opportunity perception } & Opportunity recognition \\
\hline & & Freedom and property \\
\hline & \multirow{2}{*}{ Startup skills } & Skill perception \\
\hline & & Education \\
\hline & \multirow{2}{*}{ Risk acceptance } & Risk perception \\
\hline & & Country risk \\
\hline & \multirow{2}{*}{ Networking } & Know entrepreneurs (knowent) \\
\hline & & Connectivity \\
\hline & \multirow{2}{*}{ Cultural support } & Carrier status (carstat) \\
\hline & & Corruption \\
\hline \multirow{8}{*}{ Abilities sub-index } & \multirow{2}{*}{ Startup opportunities } & Opportunity motivation \\
\hline & & Tax governance \\
\hline & \multirow{2}{*}{ Technology absorption } & Technology level (techsect) \\
\hline & & Technology absorption \\
\hline & \multirow{2}{*}{ Human capital } & High education \\
\hline & & Labor market \\
\hline & \multirow{2}{*}{ Competition } & Competitors \\
\hline & & Competitiveness and regulation \\
\hline \multirow{10}{*}{ Aspirations sub-index } & \multirow{2}{*}{ Product innovation } & New product \\
\hline & & Technology transfer \\
\hline & \multirow{2}{*}{ Process innovation } & New technology \\
\hline & & Science \\
\hline & \multirow{2}{*}{ High growth } & Gazelle \\
\hline & & Finance and strategy \\
\hline & \multirow{2}{*}{ Internationalization } & Export \\
\hline & & Economic complexity \\
\hline & \multirow{2}{*}{ Risk capital } & Informal investment \\
\hline & & Depth of the capital market \\
\hline
\end{tabular}

members are innovation-driven countries (Czech Republic, Estonia, Slovakia, and Slovenia) and only one member can be considered a resource-driven country (Kazakhstan).

\section{Results: Analyzing Innovation's Role in National Entrepreneurial Ecosystems}

First, we analyzed the relationship between GEI and the innovation-related pillar scores. We conducted a correlation analysis between the GEI super index and its three innovation-related pillars. The re- sults suggest that all coefficients are relatively high (strong-medium) and indicate the relationship between the pillars of the entrepreneurial ecosystem. Only small differences among the coefficients of the innovation-related pillars can be observed (Table 5).

In order to obtain a deeper understanding of the role of innovation within the entrepreneurial ecosystem, the aforementioned four groups of the countries were compared to each other by the scores of innovation GEI pillars ${ }^{3}$. The values of innovation pillars in the four groups were compared to each other (Figure 1). The resource-driven countries have the

\footnotetext{
${ }^{3}$ While GEI and its sub-index scores are measured on a 0 to 100 scale, a 0 to 1 scale is applied in the case of the pillars.
} 
Table 3. The Innovation-Related Pillars of GEI

\begin{tabular}{|l|l|l|}
\hline \multicolumn{1}{|c|}{ Pillar } & \multicolumn{1}{|c|}{ Components of individual variables } & \multicolumn{1}{|c|}{ Components of institutional variables } \\
\hline $\begin{array}{l}\text { Technology } \\
\text { Absorption }\end{array}$ & $\begin{array}{l}\text { Technology Level: Percentage of the } \\
\text { nascent and young firms that are active } \\
\text { in technology sectors (high or medium) } \\
\text { (Source: Global Entrepreneurship Monitor) }\end{array}$ & $\begin{array}{l}\text { Firm-level technology absorption capability (Source: World } \\
\text { Economic Forum) }\end{array}$ \\
\hline Product Innovation & $\begin{array}{l}\text { Percentage of the nascent and young } \\
\text { firms offering products that are new to } \\
\text { at least some customers (Source: Global } \\
\text { Entrepreneurship Monitor) }\end{array}$ & $\begin{array}{l}\text { A complex measure of innovation including investment in research } \\
\text { and development (R\&D) by the private sector, the presence of high- } \\
\text { quality research institutions, collaboration in research between } \\
\text { universities and industry, and the protection of intellectual property. } \\
\text { (Source: World Economic Forum) }\end{array}$ \\
\hline Process Innovation & $\begin{array}{l}\text { Percentage of the TEA businesses using } \\
\text { new technology that is less than five } \\
\text { years old on average (including one year) } \\
\text { (Source: Global Entrepreneurship Monitor) }\end{array}$ & $\begin{array}{l}\text { A complex measure of national conditions of science including } \\
\text { Gross domestic Expenditure on Research \& Development (GERD) } \\
\text { as a percentage of GDP, the quality of scientific research institutions, } \\
\text { and the availability of scientists and engineers. (Sources: World } \\
\text { Economic Forum and Eurostat) }\end{array}$ \\
\hline \multicolumn{2}{|l|}{ Source: compiled by the authors. } \\
\hline
\end{tabular}

lowest values for all three pillars. However, this group is relatively closer to the other clusters in product innovation than in the case of the two other pillars. A similar trend could be observed in the case of efficiency-driven countries. The values of Technology Absorption and Process Innovation pillars are higher than those of resource-driven countries, but these are relatively low compared to the value of Product Innovation. Innovation-driven countries have the highest innovation pillar scores compared with the other groups. In our case, the transition countries have moderate scores in Technology Absorption and Process Innovation, albeit they are higher than the values of resource- and efficiency-driven groups. In the case of Product Innovation, the same trend can be observed in other groups. The value of transition countries is almost equal to the value of efficiencydriven countries, but it lags behind the score of the innovation-driven group.

We compared the GEI and its pillar scores of certain countries in each of the four groups (Table 6). Resource-driven countries are mostly in the lowest third of the sample. For them, innovation seems to be a hindering bottleneck. This is the case in Botswana and Kazakhstan since their GEI scores are relatively higher than their innovation pillar scores. India suggests a slightly different pattern since its Technology Absorption score is one of the lowest in the whole Asian region, which may indicate the underdeveloped industry structure of the economy. However, the Product and Process Innovation pillars imply that India has a relatively strong performance in innovation.

Efficiency-driven countries have moderate GEI scores compared to the other groups and their pillar values suggest a mixed picture. It can be observed that all of the involved countries demonstrate outstanding performance in Product Innovation, but the position of the two other innovation pillars lag behind. Technology Absorption seems to be one of the bottlenecks in the Chinese entrepreneurial ecosystem. The innovation-driven countries have the best GEI scores within the whole sample which suggests that their entrepreneurial ecosystems and their components demonstrate relatively good performance. However, a few outlier pillars can be observed in their case as well, as it is suggested by Australia's position in Product Innovation. Our special group, the transition countries also indicate a mixed picture, since there are relatively large differences in

\section{Table 4. Countries According to Their Level of Development}

\begin{tabular}{|l|l|}
\hline \multicolumn{1}{|c|}{ Type of economy } & \multicolumn{1}{c|}{ Countries } \\
\hline $\begin{array}{l}\text { Resource-driven } \\
\text { countries }\end{array}$ & $\begin{array}{l}\text { Algeria, Angola, Bolivia, Botswana, Burkina Faso, Cameroon, Ethiopia, Ghana, India, Kazakhstan, Libya, } \\
\text { Malawi, Nigeria, Pakistan, Philippines, Senegal, Uganda, Vietnam, Zambia }\end{array}$ \\
\hline $\begin{array}{l}\text { Efficiency-driven } \\
\text { countries }\end{array}$ & $\begin{array}{l}\text { Argentina, Barbados, Belize, Bosnia and Herzegovina, Brazil, Bulgaria, Chile, China, Colombia, Costa, Rica, } \\
\text { Croatia, Ecuador, Egypt, El Salvador, Georgia, Guatemala, Hungary, Indonesia, Iran, Jamaica, Jordan, Latvia, } \\
\text { Lebanon, Lithuania, Macedonia, Malaysia, Mexico, Morocco, Namibia, Panama, Peru, Poland, Romania, } \\
\text { Russia, Saudi, Arabia, South, Africa, Suriname, Thailand, Trinidad and Tobago, Tunisia, Turkey, Uruguay }\end{array}$ \\
\hline $\begin{array}{l}\text { Innovation-driven } \\
\text { countries }\end{array}$ & $\begin{array}{l}\text { Australia, Austria, Belgium, Canada, Cyprus, Czech Republic, Denmark, Estonia, Finland, France, Germany, } \\
\text { Greece, Hong Kong (China), Ireland, Irael, Italy, Japan, Korea, Luxembourg, Netherlands, Norway, Portugal, } \\
\text { Puerto Rico, Qatar, Singapore, Slovakia, Slovenia, Spain, Sweden, Switzerland, Taiwan, United Arab Emirates, } \\
\text { United Kingdom, United States }\end{array}$ \\
\hline Transition countries & $\begin{array}{l}\text { Bosnia and Herzegovina, Bulgaria, Croatia, Czech Republic, Estonia, Georgia, Hungary, Kazakhstan, Latvia, } \\
\text { Lithuania, Macedonia, Poland, Romania, Russia, Slovakia, Slovenia }\end{array}$ \\
\hline Source: compiled by the authors.
\end{tabular}


Table 5. The Results of Correlation Analysis between the GEI Score and Three Innovation Pillars

\begin{tabular}{|l|r|r|r|r|}
\hline & GEI score & \multicolumn{1}{|c|}{$\begin{array}{c}\text { Technology } \\
\text { Absorption }\end{array}$} & $\begin{array}{c}\text { Product } \\
\text { Innovation }\end{array}$ & Process Innovation \\
\hline GEI score & 1 & & & \\
\hline Technology Absorption & 0.869 & 1 & & 1 \\
\hline Product Innovation & 0.724 & 0.601 & 0.778 & 0.659 \\
\hline Process Innovation & 0.761 & & \\
\hline Source: compiled by the authors. & \multicolumn{3}{|l}{} \\
\hline
\end{tabular}

the performance of the entrepreneurial ecosystem despite having the same level of GDP per capita. It can, however, be observed across the sample that the Product Innovation pillar has a much lower position than other innovation pillars and GEI scores. This suggests that Product Innovation is a general bottleneck in the entrepreneurial ecosystem of transition countries, and it may indicate to the low performance in research and development at private firms in transition countries.

Finally, we conducted k-means cluster analysis to demonstrate whether countries with the same level of development are ranked in a common group if they are clustered by the values of the three innovation pillars. We ran the cluster analysis with different configurations and tested ${ }^{4}$ them. In the end, we selected the solution with four groups (Table 7 , Table 8).

Cluster 1 involves about the half of the countries. Its members are only resource- and efficient-driven countries. This group has the lowest values in all of the innovation pillars and according to the GEI score. This low value can be explained by the lack of basic conditions for innovative capacities. However, the score of entrepreneurial attitudes is relatively high compared to the other sub-index values. Cluster 2 is a quite mixed group in terms of the level of economic development. Its Aspirations sub-index value is relatively high compared to the two other sub-indexes and its score in Product Innovation is significantly higher than the values of other innovation pillars. Besides the score of the Product Innovation pillar, the values of the High Growth pillar contribute to the relatively high sub-index score. Indeed, a couple of efficiency-driven countries like China or Turkey have an outstanding score in Product Innovation even though their overall GEI scores represent only a moderate entrepreneurial ecosystem. Cluster 3 represents the opposite trend. Its Technology Absorption and Process Innovation scores are relatively high, but the Product Innovation value is relatively low. Although there is not too much variation in the economic performance of Cluster 2 and 3, the role of in- novation in these groups seems to be quite different. Technology Absorption and Process Innovation refer to the high-tech firms and employment in high tech and knowledge-intensive sectors, as well as the technology level of firms and the availability of scientists. Product Innovation indicates the number of patents. It may mean that countries in Cluster 2 focus rather on research and development, but the results of this effort cannot be exploited by new and productive firms. On the other hand, Product Innovation seems to be a bottleneck in countries of Cluster 3. Cluster 4 involves only innovation-driven countries, which are the most developed ones. Their innovation pillar values are relatively in balance, which may mean
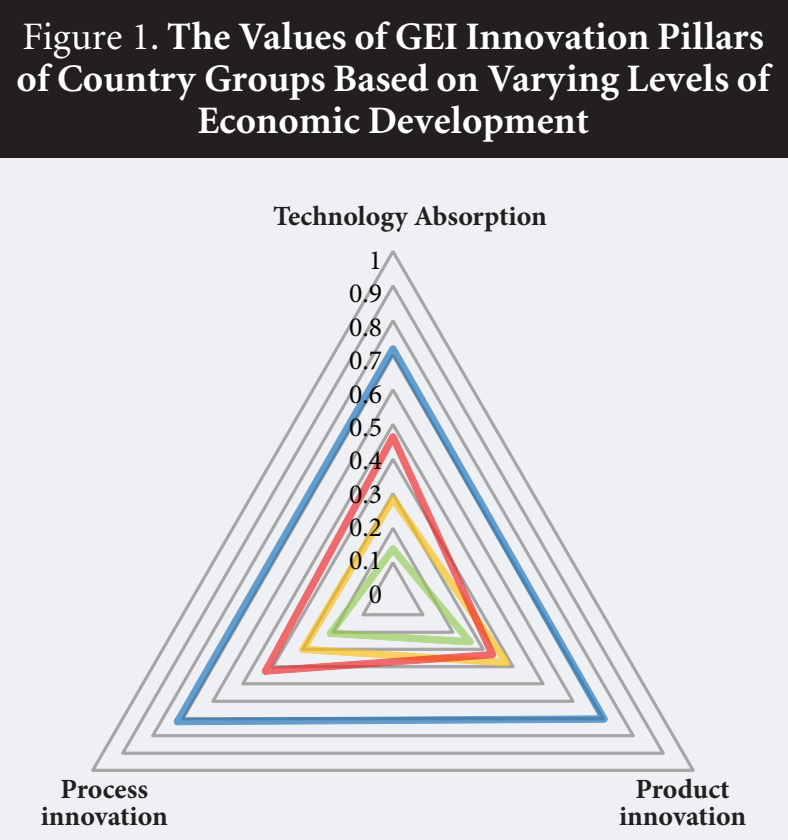

Models of economic development

Resource-driven

Efficiency-driven

- Transition countries

Innovation-driven

Source: compiled by the authors.

\footnotetext{
${ }_{4}$ Three different tests have been run: Calinski-Harabasz pseudo F-test, analysis of variance (ANOVA), and Bartlett test.
} 


\section{Table 6. Country-Level Comparison within the Development Groups (Values)}

\begin{tabular}{|c|c|c|c|c|c|c|c|c|c|c|c|c|}
\hline & \multicolumn{3}{|c|}{$\begin{array}{c}\text { Resource-driven } \\
\text { countries }\end{array}$} & \multicolumn{3}{|c|}{$\begin{array}{c}\text { Efficiency-driven } \\
\text { countries }\end{array}$} & \multicolumn{3}{|c|}{$\begin{array}{c}\text { Innovation-driven } \\
\text { countries }\end{array}$} & \multicolumn{3}{|c|}{ Transition countries } \\
\hline & 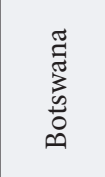 & $\underset{\Xi}{\stackrel{\Xi}{\Xi}}$ & 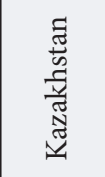 & 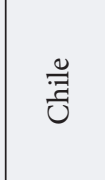 & : & $\frac{\widehat{\bar{y}}}{\stackrel{\widehat{y}}{\Xi}}$ & $\frac{\stackrel{\pi}{3}}{\stackrel{\pi}{ت}}$ & 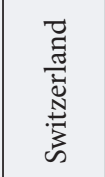 & 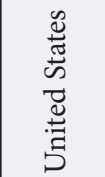 & 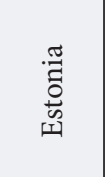 & 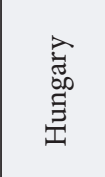 & 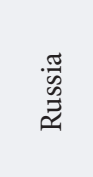 \\
\hline GEI & 34.3 & 26.3 & 30.0 & 59.0 & 35.9 & 45.0 & 74.9 & 78.9 & 82.5 & 56.0 & 39.4 & 24.7 \\
\hline 1. Opportunity Perception & 0.753 & 0.288 & 0.272 & 0.925 & 0.132 & 0.399 & 0.957 & 0.732 & 0.875 & 0.828 & 0.314 & 0.133 \\
\hline 2. Startup Skills & 0.276 & 0.198 & 0.427 & 0.894 & 0.184 & 0.688 & 1.000 & 0.688 & 1.000 & 0.657 & 0.335 & 0.353 \\
\hline 3. Risk Perception & 0.635 & 0.385 & 0.132 & 0.751 & 0.509 & 0.250 & 0.705 & 0.922 & 0.936 & 0.620 & 0.406 & 0.273 \\
\hline 4. Networking & 0.393 & 0.125 & 0.547 & 0.770 & 0.461 & 0.390 & 0.580 & 0.563 & 0.521 & 0.515 & 0.338 & 0.419 \\
\hline 5. Cultural Support & 0.760 & 0.184 & 0.213 & 0.719 & 0.299 & 0.414 & 0.769 & 0.680 & 0.838 & 0.540 & 0.364 & 0.150 \\
\hline 6. Startup Opportunities & 0.384 & 0.292 & 0.369 & 0.684 & 0.250 & 0.365 & 0.867 & 0.925 & 0.753 & 0.567 & 0.438 & 0.215 \\
\hline 7. Technology Absorption & 0.232 & 0.045 & 0.114 & 0.504 & 0.200 & 0.490 & 0.847 & 0.939 & 0.852 & 0.664 & 0.519 & 0.276 \\
\hline 8. Human Capital & 0.408 & 0.310 & 0.791 & 0.577 & 0.419 & 0.336 & 0.931 & 0.836 & 1.000 & 0.485 & 0.471 & 0.683 \\
\hline 9. Competition & 0.365 & 0.626 & 0.239 & 0.433 & 0.300 & 0.361 & 0.594 & 0.950 & 0.983 & 0.615 & 0.269 & 0.185 \\
\hline 10. Product Innovation & 0.204 & 0.644 & 0.215 & 1.000 & 0.878 & 0.925 & 0.560 & 0.828 & 0.804 & 0.569 & 0.278 & 0.151 \\
\hline 11. Process Innovation & 0.146 & 0.574 & 0.167 & 0.301 & 0.647 & 0.402 & 0.772 & 0.856 & 0.922 & 0.681 & 0.441 & 0.310 \\
\hline 12. High Growth & 0.510 & 0.187 & 0.554 & 0.702 & 0.607 & 0.797 & 0.651 & 0.599 & 1.000 & 0.586 & 0.456 & 0.379 \\
\hline 13. Internationalization & 0.273 & 0.288 & 0.303 & 0.480 & 0.252 & 0.391 & 0.675 & 1.000 & 1.000 & 0.697 & 0.748 & 0.066 \\
\hline 14. Risk Capital & 0.131 & 0.144 & 0.329 & 0.608 & 0.756 & 0.762 & 1.000 & 1.000 & 1.000 & 0.333 & 0.342 & 0.221 \\
\hline GDP per Capita & 15271 & 5578 & 23509 & 22160 & 12765 & 21871 & 43881 & 56395 & 51884 & 26772 & 23946 & 24732 \\
\hline
\end{tabular}

that innovation does not serve as a bottleneck in their entrepreneurial ecosystem. In summary, it can be concluded that innovation has an important role in the entrepreneurial ecosystem, but the intensity of this role can be very varied among countries.

\section{Conclusion}

The aim of our paper was to examine the role of innovation within the national Entrepreneurial Ecosystem. In this way, we aimed to uncover the differences in the innovative performance of the selected countries. The GEI index and its three innovation pillars (Technology Absorption, Product Innovation, and Process Innovation) were applied for this investigation. Altogether 95 countries were involved in our analysis. Countries were initially grouped by their level of development and one special group was created that involved transition countries.

Our results suggest that the quality of the entrepreneurial ecosystem reflects the level of economic development. Innovation-driven countries have the highest GEI scores. Besides the high level of GEI

\section{Table 7. Groups of Countries according to their Cluster Membership}

\begin{tabular}{|l|l|}
\hline Cluster 1 & $\begin{array}{l}\text { Algeria, Angola, Argentina, Barbados, Belize, Bosnia and Herzegovina, Botswana, Brazil, Bulgaria, Burkina, Faso, } \\
\text { Cameroon, Costa, Rica, Ecuador, Egypt, El Salvador, Ethiopia, Georgia, Ghana, Indonesia, Iran, Jamaica, Kazakhstan, } \\
\text { Libya, Macedonia, Malaysia, Mexico, Namibia, Nigeria, Pakistan, Panama, Peru, Philippines, Puerto, Rico, Romania, } \\
\text { Russia, Saudi Arabia, Senegal, Suriname, Thailand, Trinidad and Tobago, Uganda, Uruguay, Vietnam, Zambia }\end{array}$ \\
\hline Cluster 2 & $\begin{array}{l}\text { Bolivia, Chile, China, Colombia, Cyprus, Guatemala, Hong Kong, India, Jordan, Lebanon, Malawi, Morocco, Poland, } \\
\text { Qatar, South Africa, Turkey, United Arab Emirates }\end{array}$ \\
\hline Cluster 3 & $\begin{array}{l}\text { Croatia, Czech Republic, Estonia, Greece, Hungary, Latvia, Lithuania, Norway, Portugal, Slovakia, Slovenia, Spain, } \\
\text { Tunisia }\end{array}$ \\
\hline Cluster 4 & $\begin{array}{l}\text { Australia, Austria, Belgium, Canada, Denmark, Finland, France, Germany, Ireland, Israel, Italy, Japan, Korea, } \\
\text { Luxembourg, Netherlands, Singapore, Sweden, Switzerland, Taiwan, United Kingdom, United States }\end{array}$ \\
\hline Source: compiled by the authors.
\end{tabular}


Table 8. Clustering of Countries by their Innovation Pillar Values

\begin{tabular}{|l|l|l|l|l|}
\hline & \multicolumn{1}{|c|}{ Cluster 1 } & \multicolumn{1}{c|}{ Cluster 2 } & \multicolumn{1}{c|}{ Cluster 3 } & \multicolumn{1}{c|}{ Cluster 4 } \\
\hline Number of Members & 44 & 17 & 13 & 21 \\
\hline Technology Absorption & 0.199 & 0.287 & 0.615 & 0.831 \\
\hline Product Innovation & 0.233 & 0.744 & 0.384 & 0.798 \\
\hline Process Innovation & 0.208 & 0.437 & 0.541 & 0.824 \\
\hline Attitudes & 27.5 & 36.6 & 42 & 61.3 \\
\hline Abilities & 25.2 & 34.7 & 45.6 & 67.9 \\
\hline Aspirations & 21.7 & 43.8 & 45.8 & 67.5 \\
\hline GEI score & 24.8 & 38.4 & 44.5 & 65.6 \\
\hline GDP per Capita & 12928 & 25133 & 27607 & 46345 \\
\hline Source: compiled by the authors. & & & \\
\end{tabular}

scores, their pillar values seem to be relatively balanced and this points to the high quality of the entrepreneurial ecosystem. Despite having a similar level of economic development, the efficiency-driven countries have rather heterogeneous entrepreneurial ecosystems. They have moderate performance in their GEI scores. The resource-driven countries involve the lowest level of development and have the lowest GEI scores. Most of the pillar values are in the lowest third of the sample as well, only a few pillars occupy a higher position than the GEI score. The transition countries offer the most variegated picture in the entrepreneurial ecosystem due to the very different development paths of these countries since the 1990s. Not any pillar or group of pillars (including innovation-related pillars) have a dominant role in these countries, but the pillar scores in these countries are significantly below the potential performance determined by the level of economic development. According to the GEI scores, Baltic countries and a few Central European countries (Slovenia, Czech Republic, and Slovakia) have rather successful development paths.

Regarding the role of innovation, it seems that the innovation pillars have an important role within the entrepreneurial ecosystem. Technology Absorption is highly related to the GEI score and level of economic development since the most developed countries have the highest values for this pillar. The
Product and Process Innovation pillars have a relatively strong relationship with the GEI score as well. However, it seems that a couple of countries have higher pillar values than their GEI scores might suggest (like China, Turkey, or India). This may indicate that these countries have relatively good performance in research and development, but other components of their entrepreneurial ecosystem hamper the exploitation of the results by new firms.

Although GEI serves as an adequate basis for assessing a country's entrepreneurial ecosystem, it has to be noted that the GEI three sub-indexes of attitudes, abilities, and aspiration, their 14 pillars, 28 variables, and 49 indicators only partially capture the National System of Entrepreneurship, which limits its general use for policy purposes. Besides the analysis with the application of GEI, further case studies and empirical research might be useful in order to investigate those strengths and weaknesses that were identified in detail.

Eva Komlosi was supported by the Higher Education Institutional Excellence Programme of the Ministry for Innovation and Technology in Hungary, within the framework of the fourth thematic program "Enhancing the Role of Domestic Companies in the Reindustrialization of Hungary" of the University of Pecs. Balazs Pager and Gabor Markus were supported by OTKA-K-120289 entitled "Entrepreneurship and competitiveness in Hungary based on the GEM surveys 2017-2019", the authors give thanks for it.

\section{References}

Acs J.Z., Stam E., Audretsch D.B., O'Connor A. (2017) The lineages of the entrepreneurial ecosystem approach. Small Business Economics, vol. 49, no 1, pp. 1-10.

Acs Z.J., Audretsch D.B., Feldman M. (1994) R\&D Spillovers and recipient firm size. Review of Economics and Statistics, vol. 76, no 2, pp. 336-340.

Ács Z.J., Autio E., Szerb L. (2014) National Systems of Entrepreneurship: Measurement issues and policy implications. Research Policy, vol. 43, no 3, pp. 476-494.

Acs Z.J., Szerb L. (2011) Global Entrepreneurship and Development Index 2011, Cheltenham (UK), Northampton, MA (US): Edward Elgar. 
Acs Z.J., Szerb L. (2012) Global Entrepreneurship and Development Index 2012, Cheltenham (UK), Northampton, MA (US): Edward Elgar.

Acs Z.J., Szerb L., Lafuente E., Lloyd A. (2018) Global Entrepreneurship and Development Index 2018, Heidelberg, Dordrecht, London, New York: Springer.

Acs Z.J., Varga A. (2002) Geography, endogenous growth and innovation. International Regional Science Review, vol. 25, no 1, pp. 132-148.

Acs Z.J., Szerb L. (2016) Extension of the GEDI-indicator (FIRES report), Utrecht: University of Utrecht. Available at: https:// projectfires.eu/wp-content/uploads/2018/07/d4.1-report-on-extension-of-the-gedi-indicator.pdf, accessed 24.02.2019.

Alvedalen J., Boschma R. (2017) A critical review of entrepreneurial ecosystems research: Towards a future research agenda. European Planning Studies, vol. 25, no 6, pp. 887-903.

Anselin L., Varga A., Acs J.Z. (1997) Local geographic spillovers between university research and high technology innovations. Journal of Urban Economics, vol. 42, no 3, pp. 422-448.

Audretsch D., Feldman M.P. (2004) Knowledge spillovers and the geography of innovation. Handbook of Regional and Urban Economics, Cities and Geography (eds. J.V. Henderson, J.-F.Thisse), vol. 4, Amsterdam: Elsevier, pp. 2713-2739.

Boschma R. (2005) Proximity and Innovation: Critical Assessment. Regional Studies, vol. 39, no 1, pp. 61-74.

Carlsson B. (2006) Internationalization of innovation systems: A survey of the literature. Research Policy, vol. 35, no 1, pp. 56-67.

Carlsson B., Jacobsson S., Holmén M., Rickne A. (2002) Innovation systems: Analytical and methodological issues. Research Policy, vol. 31, no 2, pp. 233-245.

Cavallo A. Ghezzi A., Balocco R. (2018) Entrepreneurial ecosystem research: Present debates and future directions. International Entrepreneurship Management Journal. DOI: 10.1007/s11365-018-0526-3. Available at: https://www.researchgate.net/ profile/Angelo_Cavallo/publication/325563401_Entrepreneurial_ecosystem_research_present_debates_and_future_ directions/links/5b1909ec45851587f2986cc4/Entrepreneurial-ecosystem-research-present-debates-and-future-directions. pdf?origin=publication_detail, accessed 15.02.2019.

Coase R.H. (1992) The Institutional Structure of Production. American Economic Review, vol. 82, no 4, pp. 713-719.

Coase R.H. (1998) The New Institutional Economics. American Economic Review, vol. 88, no 2, pp. 72-74.

Cooke P. (2001) Regional Innovation Systems, Clusters, and Knowledge Economy. Industrial and Corporate Change, vol. 10, no 4, pp. 945-974.

Dosi G. (1988) The Nature of the Innovation Process. Technical Change and Economic Theory (eds. G. Dosi, C. Freeman, R. Nelson, G. Silverberg, L. Soete), London: Pinter, pp. 221-238.

Edquist C. (ed.) (1997) Systems of Innovation: Technologies, Institutions and Organizations, London: Pinter Publishers.

Feldman M.P. (1999) The New Economics of Innovation, Spillovers and Agglomeration: A Review of Empirical Studies. Economics of Innovation and New Technology, vol. 8, no 12, pp. 5-25.

Freeman C. (1982) The Economics of Industrial Innovation (2nd ed.), Cambridge, MA: MIT Press.

Freeman C. (1995) The 'National System of Innovation' in historical perspective. Cambridge Journal of Economics, vol. 19, no 1 , pp. 5-24.

Freeman C. (2002) Continental, National and Sub-national Innovation Systems - Complementarity and Economic Growth. Research Policy, vol. 31, no 2, pp. 191-211.

Jaffe A.B. (1989) Real Effects of Academic Research. American Economic Review, vol. 79, no 5, pp. 957-970.

Jaffe A.B., Trajtenberg M. (2002) Patents, Citations, and Innovations: A Window on the Knowledge Economy, Cambridge, MA: MIT Press.

Lucas R. (1988) On the Mechanics of Economic Development. Journal of Monetary Economics, vol. 22, no 1, pp. 3-42.

Lundvall B.-Å. (1988) Innovation as an Interactive Process - from User-Producer Interaction to the National System of Innovation. Technical Change and Economic Theory (eds. G. Dosi, C. Freeman, R. Nelson, G. Silverberg, L. Soete), London: Pinter, pp. 349-370.

Lundvall B.-Å. (1992) (ed.) National Systems of Innovation: Toward a Theory of Innovation and Interactive Learning, London: Pinter.

Lundvall B.-Å., Johnson B., Sloth E., Dalum A.B. (2002) National systems of production, innovation and competence building. Research Policy, vol. 31, no 2, pp. 213-231.

Mack E., Mayer H. (2016) The evolutionary dynamics of entrepreneurial ecosystems. Urban Studies, vol. 53, no 10, pp. 2118-2133.

Malecki E.J. (2018) Entrepreneurship and entrepreneurial ecosystem. Geography Compass, vol. 12, pp. 1-21.

Mason C., Brown R. (2014) Entrepreneurial ecosystems and growth oriented entrepreneurship (Background paper prepared for the workshop organised by the OECD LEED Programme and the Dutch Ministry of Economic Affairs on Entrepreneurial Ecosystems and Growth Oriented Entrepreneurship, The Hague, Netherlands), Paris: OECD.

Motoyama Y., Knowlton K. (2016) From resource munificence to ecosystem integration: The case of government sponsorship in St. Louis. Entrepreneurship \& Regional Development, vol. 28, no 5-6, pp. 448-470.

Neck H.M., Meyer G.D., Cohen B., Corbett A.C. (2004) An entrepreneurial system view of new venture creation. Journal of Small Business Management, vol. 42, no 2, pp. 190-208.

Nelson R.R. (1993) National Innovation Systems: A Comparative Analysis, Oxford: Oxford University Press.

North D. (1989) Institutions and economic growth: A historical introduction. World Development, vol. 17, no 9, pp. 1319-1332.

North D. (1990) Institutions, Institutional Change and Economic Performance, Cambridge: Cambridge University Press. 
North D.C. (1991) Institutions. Journal of Economic Perspective, vol. 5, no 1, pp. 97-112.

Qian H. (2018) Knowledge-Based Regional Economic Development: A Synthetic Review of Knowledge Spillovers, Entrepreneurship, and Entrepreneurial Ecosystems. Economic Development Quarterly, vol. 32, no 2, pp. $163-176$.

Qian H., Jung H. (2017) Solving the knowledge filter puzzle: Absorptive capacity, entrepreneurship and regional development. Small Business Economics, vol. 48, pp. 99-114.

Qian H., Acs Z.J. (2013) An absorptive capacity theory of knowledge spillover entrepreneurship. Small Business Economics, vol. 40, pp. 185-193.

Rebelo S. (1991) Long Run Policy Analysis and Long Run Growth. Journal of Political Economy, vol. 99, no 3, pp. 500-521.

Ritala P., Gustafsson R. (2018) Q\&A. Innovation and Entrepreneurial Ecosystem Research: Where Are We Now and How Do We Move Forward?. Technology Innovation Management Review, vol. 8, no 7, pp. 52-57.

Romer M.P. (1986) Increasing returns and long-run growth. Journal of Political Economy, vol. 94, no 5, pp. $1002-1037$.

Roundy P.T. (2019) Rust belt or revitalization: Competing narratives in entrepreneurial ecosystems. Management Research Review, vol. 42, no 1, pp. 102-121.

Roundy P.T., Bradshaw M., Brockman B.K. (2018) The emergence of entrepreneurial ecosystems: A complex adaptive systems approach. Journal of Business Research, vol. 86, pp. 1-10.

Roundy P.T., Brockman B.K., Bradshaw M. (2017) The resilience of entrepreneurial ecosystems. Journal of Business Venturing Insights, vol. 8, pp. 99-104.

Spigel B., Harrison R. (2018) Toward a process theory of entrepreneurial ecosystems. Strategic Entrepreneurship Journal, vol. 12, no 1, pp. 151-168.

Stam E. (2015) Entrepreneurial Ecosystem and Regional Policy: A Sympathetic Critique. European Planning Studies, vol. 23, no 9, pp. 1759-1769.

Stam E., Spigel B. (2016) Entrepreneurial Ecosytem (USE Discussion Paper 16-13), Utrecht: University of Utrecht.

Varga A. (1998) University research and regional innovation: A spatial econometric analysis of academic knowledge transfer, Boston, MA: Kluwer Academic Publisher.

Varga A. (2000) Local academic knowledge spillovers and the concentration of economic activity. Journal of Regional Science, vol. 40, no 2, pp. 289-309.

Whitley R. (1994) Societies, Firms and Markets: The Social Structuring of Business Systems. European Business Systems (ed. R. Whitley), London: Sage Publications, pp. 5-45.

Whitley R. (1996) The Social Construct of Economic Actors: Institutions and Types of Firms in Europe and Other Market Economies. The Changing European Firm (ed. R. Whitley), London: Routledge, pp. 39-66.

Williamson O.E. (1985) The Economic Institutions of Capitalism, New York: Macmillan.

Williamson O.E. (2000) The New Institutional Economics: Taking Stock, Looking Ahead. Journal of Economic Literature, vol. 38, no 3, pp. 595-613.

Wixted B. (2009) Innovation System Frontiers: Cluster Networks and Global Value, Berlin, Heidelberg: Springer Verlag.

Zhang C., Guan J. (2017) How to identify metaknowledge trends and features in a certain research field? Evidences from innovation and entrepreneurial ecosystem. Scientometrics, vol. 113, no 2, pp. 1177-1197. 